\title{
Melanoma-Associated Antigen 6
}

National Cancer Institute

\section{Source}

National Cancer Institute. Melanoma-Associated Antigen 6. NCI Thesaurus. Code C104519.

Melanoma-associated antigen 6 ( $314 \mathrm{aa}, \sim 35 \mathrm{kDa}$ ) is encoded by the human MAGEA6 gene. This protein may enhance ubiquitin ligase activity. 